\title{
Sepedi-toets vir Spraakverstaanbaarheid
}

\author{
Sunel Fouché en Anita van der Merwe \\ Departement Kommunikasiepatologie \\ Universtiteit van Pretoria
}

\begin{abstract}
OPSOMMING
Hierdie studie was daarop gemik om 'n Sepedi-toets vir Spraakverstaanbaarheid op te stel wat die spraakverstaanbaarheid van die kliënt objektief kan evalueer en fonetiese inligting sal gee oor die aard van die spraakfoute. Die studie het voortgespruit uit die huidige behoefte aan evalueringshulpmiddels in die inheemse tale en dienslewering in die Afrikatale. Die woorde wat in die toets gebruik is, moes voldoen aan sekere fonetiese kriteria. Woorde en sinne van verskillende lengtes is ingesluit Die prosedures wat deur die toepasser gevolg word by die uitvoer van die toets, verskil by moedertaalsprekers en nie-moedertaalsprekers. Nadat die toets saamgestel is, is dit ook toegepas op vier disartriesprekers. By die uitvoer van die toets het dit geblyk dat daar wel vershille voorkom tussen die beoordeling deur moedertaalsprekers en nie-moedertaalsprekers. Bruikbare fonetiese inligting is verkry met die kwalitatiewe ontleding van die spraakproduksies. Dit wil dus voorkom of die Sepedi-toets vir Spraakverstaanbaarheid wel in die kliniese opset gebruik kan word om evaluasie meer objektief uit te voer.
\end{abstract}

\section{SUMMARY}

The aim of this study was to develop the "Sepedi-toets vir Spraakverstaanbaarheid" to objectively evaluate the speech intelligibility of the client and to give appropriate phonetic information. This study evolved from the present need for evaluation mechanisms and therapeutic services in the indigenous African languages. The words used in the test had to conform to the requirements of certain phonetic criteria. Words and sentences of differing lengths were included.The procedures followed by the test administrator were different for mother tongue speakers than those for. non-mother tongue speakers. After the compilation of the test it was applied to four dysarthria speakers. Upon execution of the test it was evident that differences in judgment of speech intelligibility exist between mother tongue and non-mother tongue speakers. Useful phonetic information was obtained through the qualitative analysis of the speech productions. It appears that the "Sepedi-toets vir Spraakverstaanbaarheid" can be used in the clinical environment to obtain a more objective evaluation of the client. '

SLEUTELWOORDE: Sẹpedi, spraakverstaanbaarheid, moedertaalspreker, nie-moedertaalspreker, woordelyste, sinslyste

Die spraak-taalterapeut wat werksaam is in SuidAfrika word daagliks gekonfronteer met die diversiteit van die land se bevolkingsamestelling. Die minderheid van spraak-taalterapeute is 'n Afrikataal magtig. Die teendeel is egter dat ' $n$ groot aantal van die potensiële kliënte slegs 'n Afrikataal magtig is. Die gevolg is dat so 'n persoon baie selde in sy moedertaal geëvalueer kan word. 'n Vraag wat kan ontstaan is of resultate wat dan verkry word, betroubaar is en of die evaluasie objektief en geldig was. Die vraag na hulpmiddels vir evaluasie en rehabilitasie vir gebruik deur die spraak-taalterapeut word al groter.

Klopper het in 1983 die Afrikaanse Toets vir Spraakverstaanbaarheid opgestel, sodat die Afrikaaanssprekende disartriespreker in sy moedertaal objektief geëvalueer kan word. Die toets van Klopper (1983) is opgestel na analogie van die "Assessment of Intelligibility of Dysarthric Speech" (Yorkston \& Beukelman, 1981). Beide hierdie toetse se ontwerp word in hierdie studie as riglyne gebruik vir die samestelling van 'n Sepedi-toets vir Spraakverstaanbaarheid.
Verskeie argumente kan aangevoer word oor die insluiting van spraakverstaanbaarheid in die evaluering van disartrie. Yorkston, Beukelman en Bell (1988) beskou verstaanbare spraak as die primêre doel van die disartriespreker. Dit is bekend dat disartrie, ongeag die onderliggende neuromotoriese oorsaak, verminderde spraakverstaanbaarheid en spraakspoed tot gevolg het (Yorkston, Beukelman \& Bell, 1988). Evaluering van die spraakverstaanbaarheid verskaf inligting aangaande die graad van die afwyking en die fonetiese aard daarvan.

Yorkston en Beukelman (1978) het bevind dat daar 'n noue verband is tussen die spraakverstaanbaarheidsmeting en die hoeveelheid inligting wat oorgedra word as bepaling van die sukses van kommunikasie. Volgens Cannito en Marquardt (1997) is die primêre doel van terapie om die spreker se verstaanbaarheid te verbeter sodat hy funksioneel kan kommunikeer. Vir effektiewe evaluering word 'n diagnostiese en prognostiese vorderingskaal vereis. Dit is van praktiese waarde by die kwantifisering van 'n persoon se vordering. Spraakverstaanbaarheidsmetings kan verstaan word sonder dat 
gedetailleerde kennis van die fisiologie van die spraakmeganisme benodig word. Die kwantitatiewe data kan dus baie maklik aan die persoon se familie oorgedra word met duidelike aanduidings van sy vordering (Yorkston \& Beukelman, 1978).

'n Spraakverstaanbaarheidtoets kan op verskillende wyses saamgestel word. Een wyse wat algemeen bekend is, is die transkripsiemetode. Dit behels die transkripsie van enkelwoorde soos die lys van Tikofsky (1970), asook die transkripsie van sinne. Black en Haagen (1963) het 'n veelvuldige keuse metode vir die meting van verstaanbaarheid, ontwikkel. Yorkston en Beukelman het ook in 1981 die toets " Assessment of Intelligibility of Dysarthric Speech" op hierdie die wyse opgestel. 'n Vergelyking tussen verskillende verstaanbaarheidsmetings het aan die lig gebring dat daar 'n hiërargie is in die verskillende metingsmetodes. Die resultate verkry met die transkripsiemetode is aansienlik laer as die wat verkry word deur die veelvuldige keuse metode ( Yorkston \& Beukelman, 1980). Klopper (1983) het die Afrikaanse Toets op dieselfde wyse as Yorkston en Beukelman (1981) opgestel, maar kyk addisioneel na die tipe fonetiese foute wat die persoon maak.

'n Baie belangrike faktor wat die meting van spraakverstaanbaarheid kan beinvloed is Iuisteraarsbekendheid. Daar moet gepoog word om oplossings te kry om hierdie faktor te kontroleer. Pogings om luisteraarsbekendheid met die spreker en inhoud te oorkom, word aangewend (Darley, Aronson \& Brown, 1975; Tikofsky, 1970; Yorkston \& Beukelman, 1980; Yorkston, Beukelman \& Bell, 1988). Die luisteraarstaak kan die meting beïnvloed, omdat sekere opdragte kontekstuele leidrade verskaf (Yorkston \& Beukelman, 1978).

Die spraakverstaanbaarheidstoetse wat opgestel word in verskillende tale kan nie absoluut volgens homogene beginsels gedoen word nie, omdat die fonotaktiese en fonologiese reëls van tale verskil. Tydens die opstel van so 'n toets moet hierdie reëls in aanmerking geneem word, omdat die taal die opsteller moet lei. Die ernstige behoefte wat dus bestaan aan hulpmiddels in 'n Afrikataal, leen hom tot verdere navorsing. In hierdie studie is 'n toets opgestel waarmee die spraakverstaanbaarheid van Sepedi-sprekers objektief geëvalueer kan word deur middel van 'n kwantitatiewe en moontlike kwalitatiewe meting van spraakverstaanbaarheid.

\section{METODE}

\section{HOOFDOEL}

Die hoofdoel van hierdie studie is om 'n Spraakverstaanbaarheidstoets in Sepedi op te stel waarmee die Spraaktaalterapeut spraakverstaanbaarheid objektief kan evalueer, wat fonetiese inligting sal gee en ook 'n aanduiding van spraakspoed by Sepedi-sprekers sal gee (Fase 1). 'n Verdere doel is om die bruikbaarheid van die toets te evalueer deur dit toe te pas op enkele disartriese sprekers (Fase 2).

\section{FASE 1}

Die doel van Fase 1 was die opstel van kriteria vir die toetsmateriaal en die samestelling van 4 woord- en sinslyste wat alternerend toegepas kan word om beoordeelaarsvertroudheid te voorkom.

\section{FASE 2}

Die hoofdoel in hierdie fase is die toepassing van die Sepedi-toets vir Spraakverstaanbaarheid op disartriesprekers en die beoordeling deur luisteraars om die betroubaarheid van die verskillende lyste te bepaal.

\section{Subdoelstellings van Fase 2}

- Vergelyking van die resultate soos verkry deur twee groepe luisteraars, nl. nie-Sepedi-sprekende luisteraars en 'n Sepedi-sprekende Iuisteraar.

- Vergelyking van die resultate van die 4 verskillende lyste wat saamgestel is ten einde te bepaal of ooreenstemmende resultate verkry word.

- Aanpassings van die kriteria en toetsprosedures van die Sepedi-toets vir Spraakverstaanverbaarheid waar nodig.

- Evaluering van die bruikbaarheid van die Sepedi-toets vir Spraak-verstaanbaarheid om fonetiese foute uit te wys d.m.v. kwalitatiewe ontledings van die kenmerkende fonetiese foute wat by die spreker voorkom.

\section{FASE 1: METODE}

Kriteria vir die samestelling van materiaal van die Sepedi-toets vir Spraakverstaanbaarheid

Die toetsmateriaal waaruit die Sepedi-toets vir Spraakverstaanbaarheid saamgestel is, voldoen aan die volgende kriteria:

- Tweelettergrepige woorde met en sonder konsonantkombinasies word ingesluit.

- Bekende woorde wat algemeen gebruik word deur Sepedi-sprekers.

- Die fonetiese eienskappe van die klanke van die woorde word gekontroleer in 'n poging om 'n moontlike aanduiding van die fonetiese afwykings te verkry.

- Daar word van 'n veelvuldige keusemetode gebruik gemaak as beoordelingsmetode waar die luisteraàr'n keuse kan maak tussen minimale woordpare wat aan hom beskikbaar gestel word.

- Sinne van verskillende lengtes word ingesluit iten einde die vermoë van die disartriespreker om langer eenhede verstaanbaar te produseer, te evalueer.

\section{Samestelling van die toetsmateriaal}

Die toets bestaan uit twee tipes woorde, nl. tweelettergrepige woorde sonder konsonantkombinasies en tweelettergrepige woorde met konsonantkombinasies. In die toets is ook 'n aantal sinne ingesluit wat in die 4 lýste gebruik kan word om spraakverstaanbaarheid en spraakspoed te meet. Elke lys bestaan uit 27 tweelettergrepige woorde en 32 sinne. Die navorser het,týdens die samestelling van die toetsmateriaal verskillende bronne geraadpleeg vir die seleksie van die materiaal (Joubert, 1996; Kriel \& Van Wyk, 1989; Kock \& Kock, 1991; Kock \& Kock, 1992; Kotze, 1990; Van Wyk; Groenewald, Prinsloo, Kock \& Taljard, 1990; Pakendorf, 1996). 


\section{Woordbou en moeilikheidsgraad}

Die KVKV woorde maak die grootste gedeelte van die toets uit omdat dit 'n ruim persentasie van die mees algemene woorde in Sepedi uitmaak. Die woorde voldoen ook aan die kriteria vir die gradering van die moeilikheidsgraad van die toetsitems. Die grootste persentasie woorde in die toets bestaan dus uit KVKV ( $K=$ konsonant; $\mathrm{V}=$ vokaal;) woorde, maar daar is ook KKVKV woorde ingesluit om moeiliker eise aan die spreker te stel. Altesaam word $18 \mathrm{KVKV}$ woorde en $9 \mathrm{KKVKV}$ woorde in elke lys getoets. Die ideaal sou wees om meer woorde by die toets in te sluit, maar daar is egter nie genoeg woorde wat aan die seleksiekriteria voldoen nie. Sekere groepe van die KVKV woorde is egter daarop gemik om spesifieke foute in plek van artikulasie uit te wys. Die konsonante wissel tussen klanke wat bilabiaal en middelalveolêrbladlinguaal is. Die meeste van die konsonante in Sepedi kom voor in hierdie gebied (Kotze, 1990).

\section{Vokale}

Die tweelettergrepige woorde met KVKV-kombinasies maak die toetsing van vokaalproduksies moontlik by die sprekers. Die volgende vokale is in hierdie studie gebruik: /a:, a, $\varepsilon, e, o, o, u:, i$ /. Die vokale / y, œ / is nie gebruik nie, omdat dit nie algemeen voorkom in Sepedi nie.

Elk van die genoemde groepe bestaan uit subgroepe waarin elke keer'n ander vokaal getoets word. Die groepe soos bo genoem is soos volg saamgestel: In elk van die drie kolomme word 'n ander vokaal gebruik. Elke ry in 'n subgroep is saamgestel uit minimale woordpare waar verskillende vokale in dieselfde konsonantomgewings voorkom. Daar is 'n toetswoord vir elke lys in elke subgroep. Die toetswoorde van elke subgroep kom uit dieselfde kolom.

Op die antwoordblad van die luisteraar verskyn daar 3 kolomme woorde wat gegroepeer is. Die luisteraar het dus 'n keuse van woorde waaruit hy die een kan kies wat hy dink die persoon gesê het. Daar kan dus bepaal word of die disartriespreker spesifieke vokaal- of konsonantverwarrings toon. Fonetiese eienskappe wat bepaal kan word wanneer 'n foutanalise van die spreker se produksies opgestel word, sluit in aspekte soos vokaalduur bv. [a-a:] en vokaalvervanging bv. [ $[\hat{\varepsilon}-\mathrm{e}]$.

In groepe 7-9 het 'n ander kriterium ten opsigte van vokaalkeuse gegeld. Die produksie van konsonantkombinasies word hoofsaaklik in hierdie afdeling geëvalueer en daarom is die vokale per spesifieke subgroep konstant gehou. Daar is hoofsaaklik gebruik gemaak van konsonantkombinasies saam met/a;, $\varepsilon,\lrcorner /$ Die KKVKV woorde in groep 9 word net eenmaal per lys gebruik in 'n spesifieke konsonantomgewing. Die vokaal [u] word gebruik, omdat dit die enigste kombinasie was waaruit 'n volledige subgroep saamgestel kon word.

\section{Konsonantomgewings}

Die vokale wat getoets word in die KKVKV-woorde het elkeen 4 alternatiewe konsonantomgewings waarin die vokaal kan voorkom, nl. pVpV - [pa:ta]; pVfV [pa:la]; fVpV - [ba:ta]; fVfV - [ma:na]. (p-plosief; f-frikatief) Die konsonantomgewings word meer as een keer herhaal in elke lys, maar telkens saam met verskillende vokale. Daar word dus in elke ry, in elke subgroep van dieselfde konsonantomgewings gébruik gemaak. In groepe 4-6 word daar spesifiek gekyk na die produksie van bilabiale en middelalveolêr-bladlinguale klanke, om inligting te verkry oor plek van artikulasiefoute. Om patroonmatigheid van die produksie van konsonantomgewings uit te skakel, is die toetswoorde van elke lys uit verskillende rye binne die groep gekies, dus kom die vokale in verskillende konsonantomgewings per lys voor.

\section{Stemgewing}

Probleme met die korrekte produksie van stemhebbende en stemlose klanke kan voorkom by disartriesprekers en verminder sodoende die spraakverstaanbaarheid (Gillmer,1982). In groep 1 is die woorde saamgestel uit woorde wat slegs verskil ten opsigte van stemgewing van die inisiële konsonant: In die eerste subgroep is spesifiek woorde geselekteer waar die inisiële konsonant stemloos is, bv. "pêpa". Die woorde in die tweede subgroep het stemhebbende inisiële konsonante, bv. "bêka". In beide subgroepe is daar gebruik gemaak van verskillende konsonantomgewings. Een woord per subgroep is vir elke lys geselekteer.

\section{Konsonantkombinasies}

Woorde waar konsonantkombinasies in die inisiële posisie staan, word gebruik om te bepaal watter konsonantkombinasies vir die disartriespreker moeilik is om korrek te produseer. Hierdie woorde is in groepe 7-8. Verskillende konsonantkombinasies is ingesluit, nl. pf-p, pf-f. Ander konsonantkombinasies soos bv. fp-p kom nie voor in Sepedi nie. In groep 9 word gebruik gemaak van konsonantkombinasies waar geaspireerde eksplosiewe in die kombinasie voorkom nl. pf-p, pf-f, bv. phaka en phala. Die toetswoorde in 'n subgroep word gekies uit dieselfde kolom. In groepe 7-9 word die vokale gewissel om dit in soveel moontlik konsonantkombinasies te toets.

\section{Sinne}

Spraakverstaanbaarheid van disartriesprekers verskil by die produksie van woorde en sinne en daarom is daar ook sinne in die Sepedi-toets ingesluit. Volgens Yorkston en Beukelman (1978), behaal persone met erge disartrie beter tellings op enkelwoorde as by sinne, omdat enkelwoorde makliker produseerbaar is. Die materiaal wat gebruik is vir die sinne is gegroepeer volgens die aantal lettergrepe per sin. Die sinslengtes varieer van 3-10 lettergrepe per sin om daardeur ook 'n variasie in die moeilikheidsgraad te bewerkstellig. Al die sinne voldoen aan die voorafbepaalde kriteria al verskil die inhoud van die verskillende sinslyste. Daar kom 15 verskillende tipes sinne voor wat verskil in terme van die aantal lettergrepe per sin en dan ook die woordlengtes. Daar word 2 sinne van elke tipe per lys getoets. Daar kom dus 32 sinne per lys voor wat 127 woorde bevat.

\section{Samestelling van verskillende lyste}

Met hierdie studie is daar na analogie van Klopper (1983), 4 verskillende woord- en-sinslyste saamgestel, as 'n poging om luisteraarsvertroudheid by die terapeut, wat die toets herhaaldelik moet toepas, te kontroleer. Daar is gepoog om die verskille tussen die lyste te kontroleer sodat al 4 lyste dieselfde fonetiese eienskappe meet. Elke lys is saamgestel uit 27 woorde wat verdeel kan word in 18 
KVKV-woorde, 9 KKVKV-woorde en 32 sinne. In die bylae word twee van hierdie lyste aangegee (Sien Bylae A)

- KVKV-woorde:

In elke lys kom daar dieselfde aantal woorde uit 'n bepaalde groep voor, met ander woorde elke lys bevat 'n toetswoord uit elke subgroep. Die toetswoorde van 'n spesifieke subgroep word uit dieselfde kolom gekies volgens die fonetiese eienskappe wat by 'n subgroep getoets word. Die woorde word egter geselekteer uit verskillende rye wat dus impliseer dat daar verskillende konsonantomgewings rondom dieselfde vokaal is. Indien daar dus bv. 3 toetswoorde uit 'n groep vir 'n spesifieke lys gekies word, word die 3 woorde elk uit'n ander kolom en 'n ander ry gekies.

- KKVKV-woorde:

Elke lys bevat'n toetswoord uit elke subgroep woorde. $\mathrm{Al}$ die woorde word gekies uit dieselfde kolom, maar uit 'n ander ry.

- Sinne:

Die sinne is saamgestel uit 15 groepe sinne waar elke tipe sin, 2 keer verteenwoordig word in elke lys. Elke lys bevat dus 32 sinne wat altesaam uit 127 woorde per lys bestaan.

\section{FASE 2: TOEPASSING VAN DIE VOORLOPIGE SEPEDI-TOETS VIR SPRAAKVERSTAANBAARHEID.}

\section{Proefpersone}

\section{Kriteria vir die seleksie van die proefpersone}

- Tipe spraakprobleem: Disartrie as gevolg van enige letsel (die toets is gerig op alle tipes disartrie). Ander toestande soos verbale apraksie of afasie sal 'n invloed hê op die tipe spraakprobleem en daarom moet daar nie enige sodanige toestand teenwoordig wees nie.

- Ouderdom: Die disartriespreker moet 'n adolessent of volwassene wees aangesien hierdie toets spesifiek gerig is op hierdie populasie. Die kompleksiteit van baie van die sinne beperk die gebruik van die toets by kinders.

- Geletterdheid: Die disartriespreker moet 'n vlak van geletterdheid hê wat hom instaat stel om die woorden-sinslyste te lees.

- Taal: Die persoon moet Sepedi-sprekend wees, sonder addisionele taalprobleme soos bo genoem.

- Geslag: Die proefpersoon kan van enige geslag wees aangesien dit nie 'n invloed op spraakverstaanbaarheid behoort te hê nie.

- Gehoor: Normale gehoor is 'n vereiste, omdat 'n gehoorverlies 'n persoon se spraakverstaanbaarheid kan beïnvloed.

\section{Seleksie van proefpersone}

Geskikte proefpersone is gevind by die Letaba Skool/ Inrigting vir Fisies Gestremdes in die Noordelike Provinsie. Al die proefpersone is serebraalgestremd en pas in by die seleksiekriteria. Die inligting aangaande die proefpersone verskyn in Tabel 1 .

\section{Luisteraars}

\section{Kriteria vir die seleksie van luisteraars}

- Persone wat voorheen al blootgestel is aan disartriespraak en dus oor kennis van disartrie beskik.

- Minstens een luisteraar wat'n Moedertaalspreker is.

\section{Seleksie van luisteraars}

Drie Afrikaanssprekende vierdejaar B. Kommunikasiepatologie studente van die Universiteit van Pretoria en een Sepedi-moedertaalspreker en ook'n B. Kommunikasiepatologie student het opgetree as luisteraars.

\section{Materiaal en apparaat}

\section{Materiaal}

Die voorlopige materiaal vir die Sepedi-toets vir Spraakverstaanbaarheid is as toetsmateriaal gebruik. Die toets bestaan uit: 4 woordlyste, 4 sinslyste, 1 luisteraarsantwoordblad, inligting aangaande die prosedure asook 'n foutanalisetabel. Elke proefpersoon het al vier lyste gelees om sodoende vas te stel of daar betekenisvolle verskille tussen die lyste voorkom

\section{Apparaat}

Die spraakproduksies is op 'n hoëkwaliteitkassetopnemer opgeneem, nl. die AIWA JS 145. Die kassetopnemer is met elektriese krag tydens die opnames aangedryf, sodat die kwaliteit van die opname deurgaans konstant gehou is. 'n TDK D 60 kasset is gebruik.

\section{Prosedure}

\section{Fisiese Opset}

Die opnames is in 'n stil kantoor by die skool gemaak. Die toetsafnemer en die proefpersoon het langs mekaar by 'n tafel gesit. Die mikrofoon is vasgesit aan die lapel van die proefpersoon se hemp, wat impliseer dat dit gemiddeld $10-15 \mathrm{~cm}$. van die spreker se mond was. Die duur van die toets was ongeveer 40 minute per spreker, die graad van aantasting het egter bygedra daartoe dat dit soms gevarieër het.

TABEL 1: Inligting aangaande proefpersone

\begin{tabular}{|c|c|c|c|c|c|c|}
\hline Proefpersoon & Etiologie & Plek van letsel & Ouderdom & Geslag & Gehoor & Spreektaal \\
\hline 1 & Kongenitaal & BMN-letsel & 18 & Vroulik & Normaal & Sepedi \\
\hline 2 & Kongenitaal & BMN-letsel & 17 & Vroulik & Normaal & Sepedi \\
\hline 3 & Kongenitaal & Serebellêr & 20 & Vroulik & Normaál & Sepedi \\
\hline 4 & Kongenitaal & $\begin{array}{c}\text { Bilaterale } \\
\text { BMN-letsel }\end{array}$ & 22 & Manlik & Normaal Sepedi & S \\
\hline
\end{tabular}




\section{Toetsprosedure}

Die proefpersoon kon die toetsmateriaal eenmaal stillees om leesfoute uit te skakel. Daarna moes hy dit hardop lees volgens die intruksies wat aan hom gegee is

Daar is tussen die lyste elke keer 'n rusperiode van 3 minute gegee om uitputting te voorkom. Tussen elke gelese woord of sin is daar'n pouse gelaat van omtrent 5 sekondes, sodat die luisteraars geleentheid het om hulle optekening te maak.

\section{Analise van die toetsresultate}

Die opnames is deurgaans afsonderlik aan die luisteraars gespeel, vanweë die beskikbaarheid van die oorfone en kassetopnemer. Die luisteraars kon slegs eenmaal na elke woord luister waarna hulle dan 'n keuse moes maak uit die beskikbare keuses in die veelvuldige keusekolom. Die prosedure van beoordeling van die sinne is verander nadat die nie-moedertaalsprekers baie probleme ondervind het met die transkripsie daarvan. As alternatief het die nie-moedertaalsprekende luisteraars die lys van gelese sinne voor hulle gehad en slegs die woorde wat as verkeerd gehoor is, gemerk.

\section{Verwerking van toetsresultate}

\section{Kwantitatiewe Analise}

Die verskillende tellings soos deur die onderskeie luisteraars aangeteken is met mekaar vergelyk. Die volgende vergelykings is met behulp van kwantitatiewe ontledings getref: tellings verkry deur die verskillende luisteraars, verskillende woordlyste, verskillende sinslyste, woord-en-sinslyste.

\section{Kwalitatiewe Analise}

Die doel van die kwalitatiewe analise is om die fonetiese foute van die spreker te identifiseer. Elke luisteraar se beoordeling van proefpersoon 4 (word gebruik omdat hy die meeste foute vertoon) is gebruik om fonetiese foute te identifiseer en vas te stel of die fonetiese indeling wel terapie leidrade kan verskaf. Die foutiewe produksies van die proefpersoon is ontleed volgens die tipe fonetiese fout, bv. die proefpersoon sê kuta maar die luisteraar hoor kita. Dit is dus ' $n$ vokaalvervanging. Die aantal foute wat voorgekom het by elke fonetiese eienskap is bymekaar getel en aangeteken op die foutanalise-tabel.

TABEL 2:'n Uiteensetting van die kwalitatiewe analise van die produksies van Proefpersoon 4, soos verkry deur die luisteraars

\begin{tabular}{|c|c|c|}
\hline Doelwit woord & Geproduseerde woord & Tipe fonetiese fout \\
\hline Dila & tila & Stemhebbend $\rightarrow$ Stemloos \\
\hline Padi & pidi & Lang vokaal $\rightarrow$ Kort vokaal \\
\hline Rufa & rifa & Agtervokaal $\rightarrow$ Voorvokaal \\
\hline Fira & fura & Voorvokaal $\rightarrow$ Agtervokaal \\
\hline Ripa & rupa & Voorvokaal $\rightarrow$ Agtervokaal \\
\hline Gêša & gaša & Voorvokaal $\rightarrow$ Middelvokaal \\
\hline Padi & pidi & Middelyokaal $\rightarrow$ Voorvokaal \\
\hline Lota & lôta & Mid hoë vokaal $\rightarrow$ Mid lae vokaal \\
\hline Tepa & têpa & Mid hoë vokaal $\rightarrow$ Mid lae vokaal \\
\hline Pôna & pona & Mid lae vokaal $\rightarrow$ Mid hoë vokaal \\
\hline Nêpa & nepa & Mid lae vokaal $\rightarrow$ Mid hoë vokaal \\
\hline Bela & bula & Mid hoë vokaal $\rightarrow$ Hoë vokaal \\
\hline Taba & huba & Lae vokaal $\rightarrow$ Hoë vokaal \\
\hline Mana' & nama & $\begin{array}{l}\text { Bilabiaal } \rightarrow \text { Middealveolêrbladlinguaal } \\
\text { (Inisiële posisie) }\end{array}$ \\
\hline Lama & mama & $\begin{array}{l}\text { Middelalveolêrbladlinguaal } \rightarrow \text { Bilabiaal } \\
\text { (Inisiële posisie) }\end{array}$ \\
\hline mana & nama & $\begin{array}{l}\text { Middelalveolêrbladlinguaal } \rightarrow \text { Bilabiaal } \\
\text { (Finale posisie) }\end{array}$ \\
\hline pešo & bešo & Eksplosief $\rightarrow$ Frikatief (Inisiële posisie) \\
\hline taba & huba & Eksplosief $\rightarrow$ Eksplosief (Inisiële posisie) \\
\hline dita & kita & Eksplosief $\rightarrow$ Eksplosief (Inisiële posisie) \\
\hline dila & tila & Eksplosief $\rightarrow$ Eksplosief (Inisiële posisie) \\
\hline bata & pata & Eksplosief $\rightarrow$ Eksplosief (Inisiële posisie) \\
\hline bôta & pôta & Frikatief $\rightarrow$ Eksplosief (Inisiële posisie) \\
\hline gaša & gasa & Frikatief $\rightarrow$ Frikatief (Finale posisie) \\
\hline mana & nama & Frikatief $\rightarrow$ Frikatief (Inisiële posisie) \\
\hline tlôka & tlôga & $\mathrm{pf}-\mathrm{p} \rightarrow \mathrm{pf}-\mathrm{f}$ \\
\hline tsama & tsaka & pf-f $\rightarrow$ pf-p \\
\hline kgaka & gaka & $p f-p \rightarrow f-p$ \\
\hline kgafa & gafa & $p f-f \rightarrow f-f$ \\
\hline
\end{tabular}




\section{RESULTATE VAN FASE 2}

Die resultate van die kwantitatiewe en kwalitatiewe analises wat verkry is tydens die toepassing van die Sepedi-toets vir Spraakverstaanbaarheid, word aan die hand van die geformuleerde subdoelstellings, soos uiteengesit in die metodologie, bespreek.

\section{KWANTITATIEWE ANALISE}

\section{Vergelyking van die resultate verkry van die twee groepe luisteraars}

Elke spreker het by elk van die luisteraars vier lyspersentasies behaal. Vir elke spreker is 'n gemiddeld bepaal, vanuit sy vier lyspersentasies ten opsigte van.'n spesifieke luisteraar' (Sien Figuur 1). Die luisteraars word in twee groepe verdeel $\mathrm{nl}$. die nie-moedertaalsprekers (NM1-NM3) en die moedertaalspreker (M1).

Uit hierdie resultate soos in Figuur 1 uiteengesit, blyk dit dat daar nie noemenswaardige verskille voorgekom het tussen die nie-moedertaalsprekende luisteraars (NM1-NM3) nie. Die beoordelings wat deur die drie verskillende luisteraars gemaak is by proefpersoon 1 verskil met $1 \%$. Die luisteraars se beoordelings van die verstaanbaarheid by die ander proefpersone verskil met $1 \%$ tot $3 \%$. Die luisteraars se waarnemings verskil kenmerkend minder by die proefpersone wat uit 'n subjektiewe oogpunt 'n geringer mate van aantasting het. Dit wil dus voorkom of die beter verstaanbaarheid van hierdie spreker, vir die nie-moedertaalsprekende luisteraar makliker was om korrek te beoordeel.

\section{Tellings soos verkry uit die vershillende woordelyste}

Die doel van hierdie vergelyking is om te bepaal of al vier die woordelyste ooreenstemmende resultate oplewer en dus ewe bruikbaar is. Die gemiddeldes wat elke proefpersoon op al vier woordelyste by die 4 luisteraars behaal het word voorgestel in Figuur 2.

Dit blyk duidelik dat die persentasies wat deur die verskillende proefpersone behaal is op die vier lyste in 'n groot mate ooreenstem. By Proefpersoon 1 wissel die persentasies wat hy behaal het by die verskillende lyste tussen $69 \%-71 \%$ (Figuur 2). Die verskille tussen die lyste vir Proefpersoon 1 is dus nie besonder groot nie. By Proefpersoon 2 kom daar'n verskil in persentasies tussen die verskillende lyste voor van $1 \%$-3\%. Dit is duidelik dat ook hier nie noemenswaardige verskille voorkom nie. 'n Verskil van $1 \%-3 \%$ het voorgekom by die persentasies wat deur Proefpersoon 3 verkry is op die verskillende lyste. By Proefpersoon 4 het daar'n verskil van $1 \%$ voorgekom tussen die verskillende woordelyste. Die ooreenstemming soos gesien in Figuur 2, blyk hier selfs groter te wees.

Die proefpersone het nie konstant beter of swakker gevaar op spesifieke lyste nie, dit blyk dus dat daar nie noemenswaardige verskille tussen die lyste bestaan nie. Wanneer hierdie resultate in ag geneem word, kan daar aanvaar word dat die verskillende lyste in 'n groot mate dieselfde eienskappe by 'n persoon evalueer. Al vier die

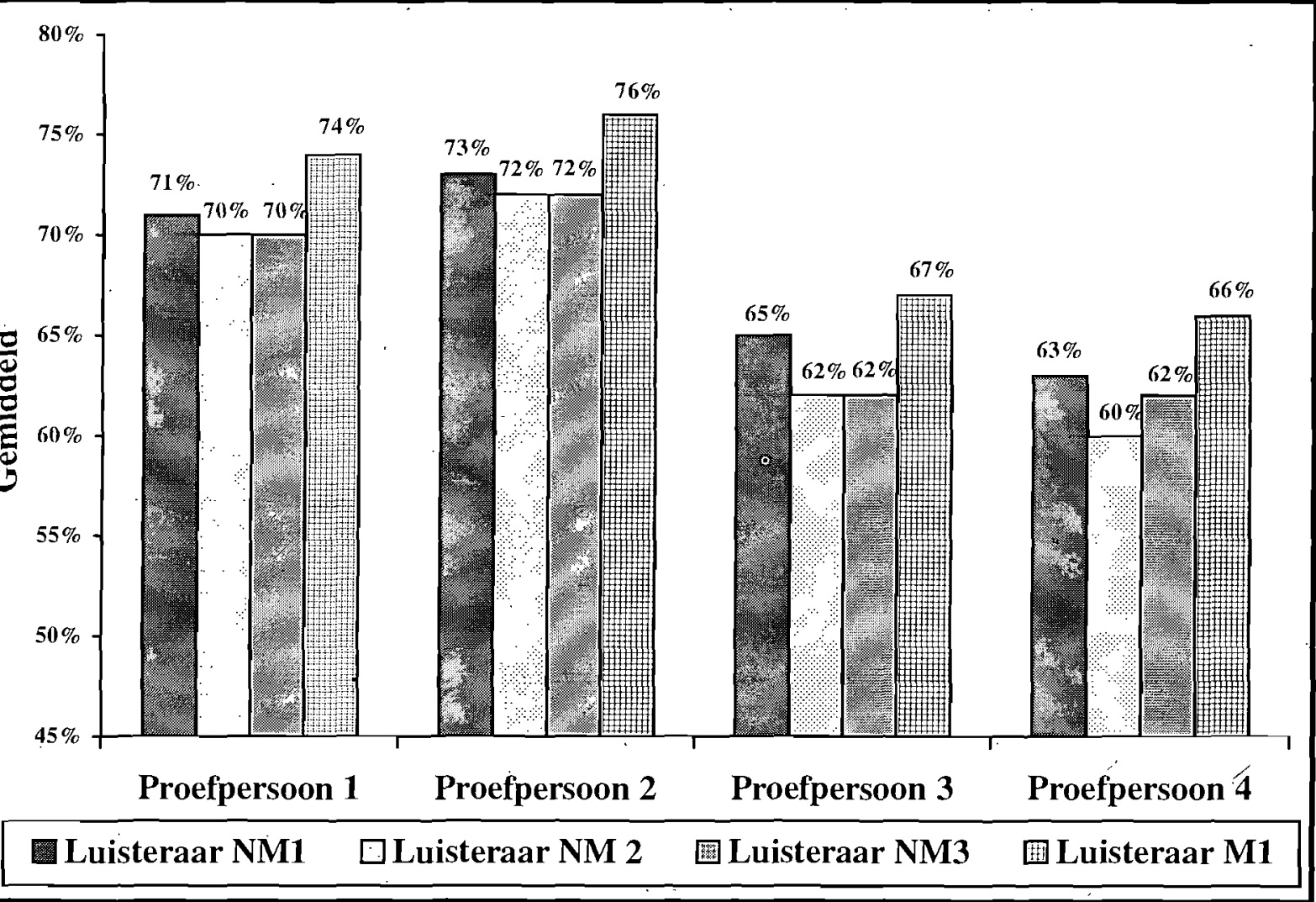

FIGUUUR 1: Gemiddelde spraakverstaanbaarheid van elke proefpersoon soos behaal op al vier lyste beoordeel deur die vier luisteraars (persentasies afgerond na die naaste heelgetal) 


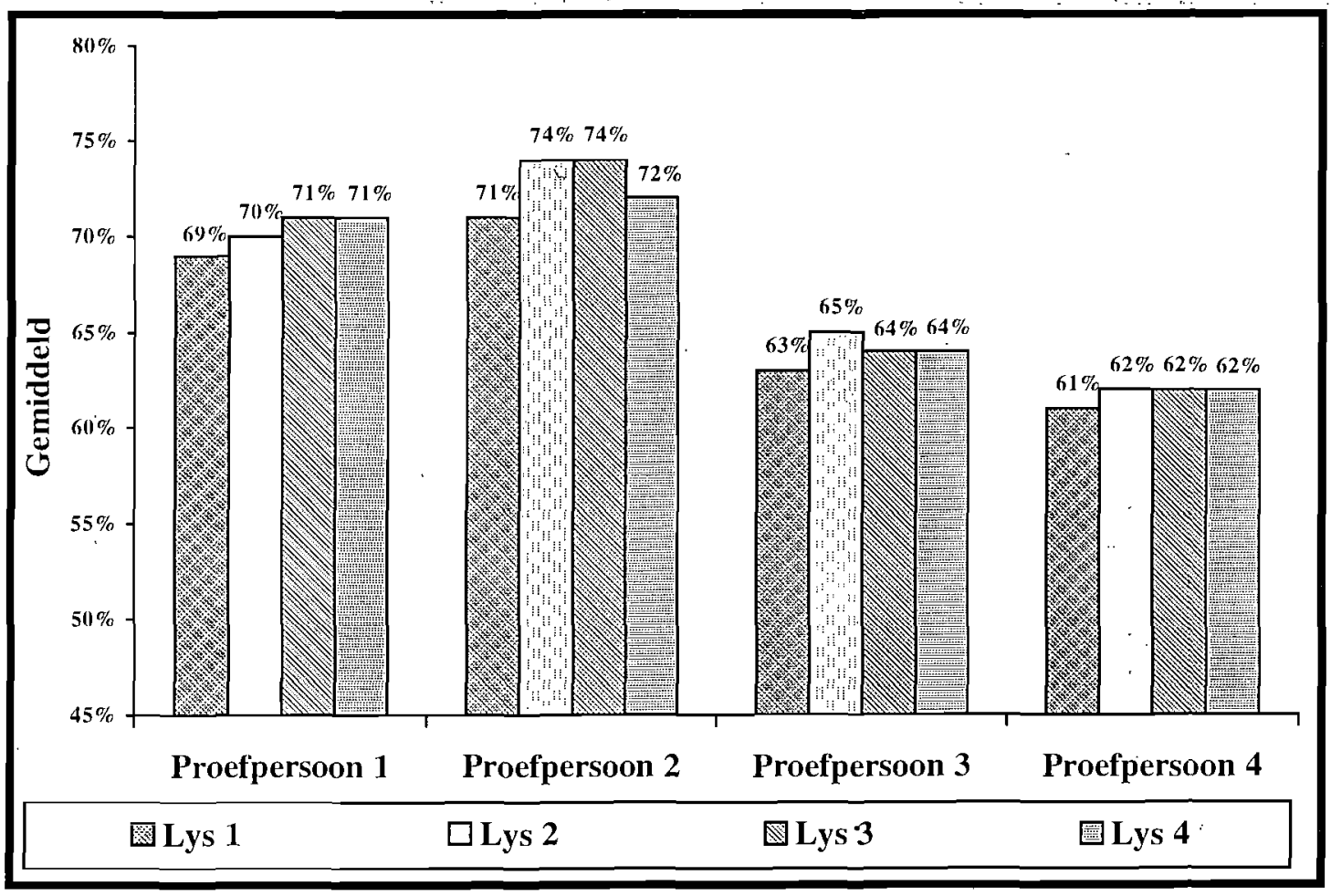

FIGUUUR 2: Gemiddeld wat elke proefpersoon op elke woordelys behaal het soos deur die twee groepe luisteraars aangeteken

lyste is dus bruikbaar om die spraakverstaanbaarheid van die Sepedi-spreker te evalueer.

\section{Resultate soos verkry uit die vershillende sinslyste}

Elke proefpërsoon se gemiddeldes vir al vier lyste soos verkry by die vier luisteraars gesamentlik, is bereken. In Figuur 3 word die gemiddeldes van die sinslyste soos bereken, weergegee.

Uit Figuur 3 blyk dit duidelik dat daar nie groot verskille in die beoordeling van die verskillende sinslyste was nie. Proefpersoon 1 behaal op drie uit die vier lyste dieselfde pérsentasie en behaal slegs $1 \%$ meer op die ander lys. By Proefpersoon 2 kom daar ook nie groot verskille tussen die lyste voor nie. 'n Verskil jvan $2 \%$ kom voor, maar Proefpersoon 2 behaal elke keer vir twee lyste dieselfde persentasie. Die persentasies vir die sinslyste wat verkry is by Proefpersoon 3 wissel tussen $78 \%-80 \%$. Op twee van die lyste het hy egter dieselfde persentasie behaal. Die persentasies wat Proefpersoon 4 behaal het op die verskillende lyste wissel van $77 \%-79 \%$. Dieselfde persentasies is behaal op lyste 1 en 2 . Die grootste variasie tussen die lyste kom dus voor by Proefpersoon 2, die variasie herhaal homself egter nie by die ander sprekers nie. Die proefpersone presteer nie konstant beter of swakker op dieselfde lyste nie, daarom kan daar aanvaar word dat die moeilikheidsgraad tussen die lyste konstant is. Wanneer hierdie resultate van die verskillende sinslyste in ag geneem word, blyk dit dat die lyste in'n groot mate dieselfde eienskappe evalueer. $\mathrm{Al}$ vier die sinslyste kan dus gebruik word om die spraakverstaanbaarheid van die Sepedispreker te evalueer.

\section{KWALITATIEWE ANALISE}

Resultate soos verkry b'y proefpersoon 4

'n Volledige uiteensetting van die kwalitatiewe foutanalise van die toetsresultate word in Tabel 2 verskaf. Die volgende fonetiese foute is by Proefpersoon 4 deur middel van die kwalitatiewe foutanalise van die enkelwoorde uitgelig:

- $\quad$ probleme met stemgewing

- verandering van die plek van artikulasie van die vokale, bv. agtervokaal (voorvokaal)

- duurveranderinge by die vokale

- konsonantveranderinge, bv. eksplosief $(\mathrm{p}) \rightarrow$ frikatief $(\mathrm{f})$

- veranderinge en vereenvoudiging van konsonantkombinasies.

Die fonetiese foute wat deur die luisteraars aangeteken is, gee 'n aanduiding dat die fonetiese kriteria van die enkelwoorde voldoende is, sodat die toets hom kan leen tot kwalitatiewe foutanalises van sprekers.

Dit is belangrik om te meld dat enkele van die foute wat deur die nie-Sepedi sprekende luisteraars aangeteken is, nie deur die moedertaalspreker wat as luisteraar opgetree het, aangeteken is nie. Uit die kwantitatiewe analise van die resultate blyk dit dat daar minder foute deur laasgenoemde luisteraar aangeteken is. Hierdie resultate korrelleer dus met die kleiner voorkoms van foute by die kwalitatiewe analise. Daar bestaan wel ooreenkomste in die evaluering en telkens is dieselfde fonetiese fout, wat deur die ander luisteraars opgemerk is, aangeteken.

Daar blyk egter sekere beperkinge te wees in die fonetiese kriteria waarvoor daar nie genoegsame voorsiening gemaak is in die veelvuldige keuse nie. Die foute wat egter voorgekom het, is nie erkende woorde in Sepedi nie, hoewel dit foneties bestaan, bv. pidi, die foute kan ook by ander sprekers verwag word. Die proefpersoon het die konsonantkombinasies vereenvoudig, bv. kgaka word uitgespreek as gaka, die prosessse kan ook verwag word by ander sprekers. Meer woordgroepe blyk nodig te 


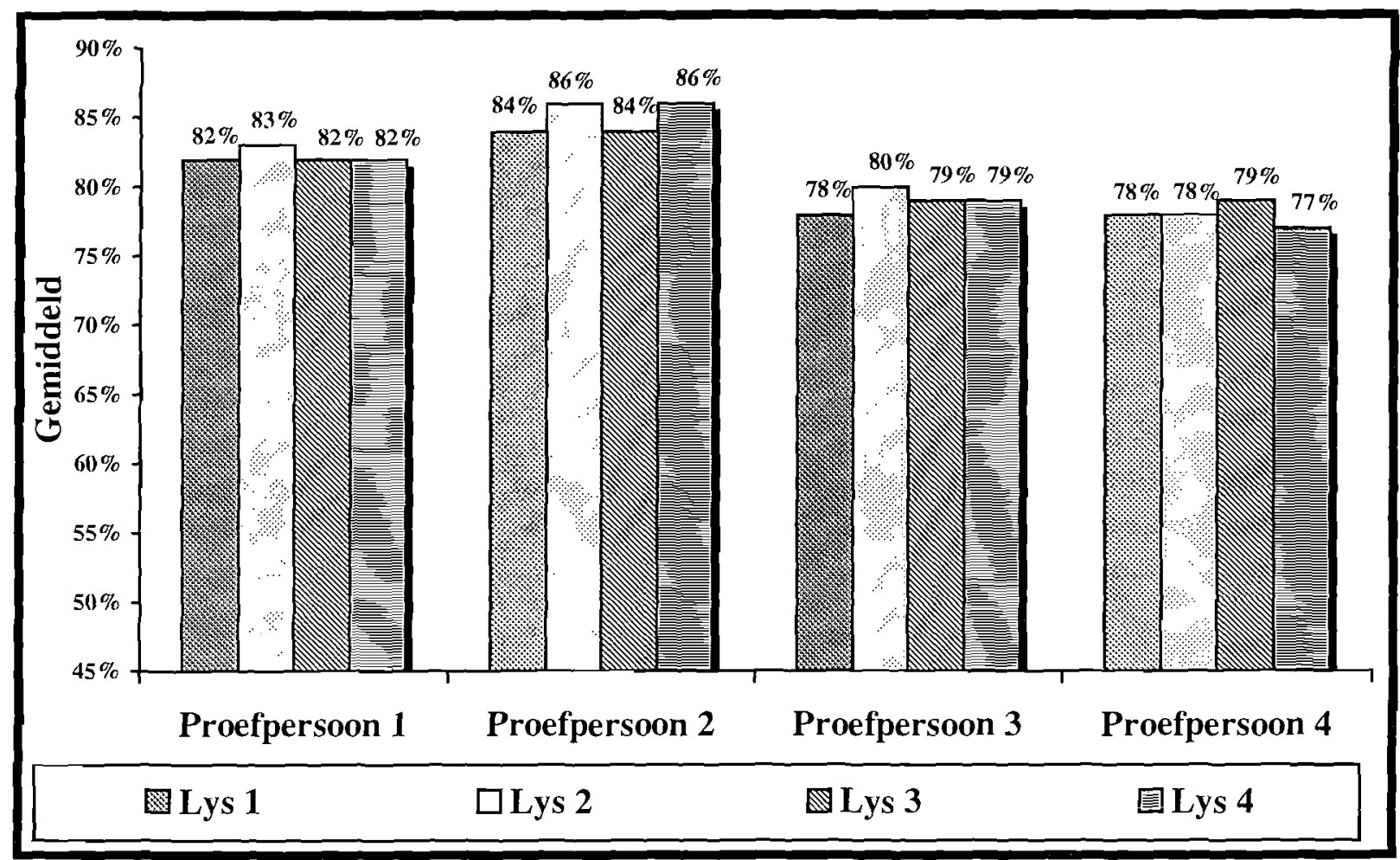

FIGUUR 3: Gemiddeld deur elke proefpersoon behaal vir al die sinslyste, soos beoordeel deur die twee groepe luisteraars gesamentlik

wees om stemgewing meer suksesvol te evalueer. Daar is egter nie nog groepe woorde wat aan die seleksiekriteria van die woorde vir die Sepedi-toets vir Spraakverstaanbaarheid voldoen nie.

\section{BESPREKING VAN RESULTATE}

Die hoofdoel van hierdie studie was om 'n Sepedi-toets vir Spraakverstaanbaarheid op te stel. Die waarde van so 'n toets is dat'n persoon se spraakverstaanbaarheid meer betroubaar in sy eie moedertaal geëvalueer kan word. Fonetiese inligting van die kliënt se spraakproduksies kan hierdeur verkry word en sodoende word die spraaktaalterapeut instaat gestel om verantwoordbare terapie aan die kliënt te gee. Tydens die uitvoer van hierdie studie was dit duidelik dat dit moontlik is om na analogie van 'n bestaande toets (Klopper, 1983), materiaal te wysig en kultureel aan te pas, sodat dit toepaslik is vir ' $n$ ander taalgroep in Suid-Afrika. Die Sepedi-toets vir Spraakverstaanbaarheid is verder ook uitgevoer op Sepedidisartriesprekers. Die resultate wat verkry is dui daarop dat die toets wel betroubaar is en in sy huidige vorm gebruik kan word.

\section{DIE STRUKTUUR VAN DIE SEPEDI-TOETS VIR SPRAAKVERSTAANBAARHEID}

- Die Sepedi-toets vir Spraakverstaanbaarheid is opgestel na analogie van die Afrikaanse Toets vir Spraakverstaanbaarheid van Klopper (1983). Tydens die opstel van die toets het dit egter duidelik geblyk dat Sepedi wat 'n Afrikataal is in ' $n$ baie groot mate verskil van Afrikaans wat ontwikkel het uit onder andere baie verskillende Europese en Maleisiese tale.

Die fonetiese repertoire van Sepedi verskil van dié van Afrikaans. Daar kom klanke voor in Sepedi wat geensins in Afrikaans gebruik word nie soos bv. die /hl/ wat uitgespreek word as / 4/. In Sepedi kom daar nie klusters voor waar die frikatief voor die eksplosief staan nie. Die navorser moes die unieke eienskappe van Sepedi in aanmerking neem en akkomodeer in 'n toets met hierdie spesifieke formaat. Woorde met KVK-struktuur kon nie ingesluit word nie, omdat dit nie voorkom in Sepedi nie.

Die verskille wat voorkom tussen die tale beklemtoon die noodsaaklikheid van 'n toets in 'n Afrikataal soveel te meer. Indien 'n Afrikaanse of Engelse toets toegepas word moet die persoon klanke produseer wat nie eie is aan sy taal nie. Die aantal woordgroepe wat in die toets ingesluit is, moes as gevolg van hierdie verskille verminder word, omdat daar nie meer groepe gevorm kon word wat aan die fonetiese kriteria voldoen nie. Die meerderheid klanke wat in Sepedi gebruik word, is egter in die toets ingesluit en dus word die toets nie nadelig geraak deur die beperkte getal groepe nie. 'n Groot voordeel wat spruit uit die minder groepe, is die feit dat die toetsafnemer meer tyd bespaar met die afneem van die toets. Ook vir die toetsling is die toets minder uitputtend.

\section{EVALUASIE DEUR DIE NIE-MOEDERTAAL SPREKER}

In die Suid-Afrikaanse konteks word die spraaktaalterapeut byna daagliks gekonfronteer met die kwessie van meertaligheid. Dit bring mee dat die terapeut met'n kliënt moet kommunikeer in 'n geradbraakte tweede of selfs derde taal. Dit wil ook voorkom asof daar slegs 'n klein persentasie van die spraak-taalterapeute in die land is, wat ook 'n Afrikataal magtig is. Nie net die spraaktaalterapeut word egter met meertaligheid gekonfronteer 
nie, maar ook die kliënt wat dalk nie in sy moedertaal geëvalueer kan word nie. Uit hierdie studie blyk dit dat die toetsafnemer se kennis van die taal waarin die toets is, wel 'n rol speel. Die spreker kan benadeel word wanneer sy spraakverstaanbaarheid geëvalueer word deur 'n niemoedertaalspreker.

Baie van die klanke wat in die repertoire van die Afrikatale voorkom, word nie in Afrikaans en Engels gebruik nie, veral wat betref die konsonantklusters en is dus vreemd vir die luisteraars. Dit is daarom vir die luisteraar moeilik om te onderskei tussen onverstaanbare spraak en duidelike, maar onbekende spraak.

Die luisteraar evalueer streng volgens dit wat op papier staan, maar selfs al is die klanke foneties geskryf op die antwoordblad, klink die uitspraak van die moedertaalspreker anders as die van die nie-moedertaalspreker. Die rede hiervoor kan toegeskryf word aan die feit dat klanke in die volksmond verandering ondergaan en nie meer altyd klink soos dit wat geskryf staan nie.

Die Sepedi wat in Pretoria gepraat word, verskil ook weer van die Sepedi wat in die noordelike streke gepraat word. Die Sepedi in Pretoria kan beskou word as 'n Koine-taal. Volgens Schuring (1984) is hierdie dialek'n meer alledaagse gesproke taal. Dit beteken dus dat daar wel variasies en strukturele vereenvoudigings van die taal voorkom. Volgens Schuring (1984) word die Pretoria-Sepedi beïnvloed deur tale soos Afrikaans, Engels, Pedi, Kgatla en nog ander tale wat in die gebied gepraat word. Die Sepedi in die noordelike streke word weer beïnloed deur tale soos Afrikaans, Engels, Sjangaan, Tsonga en ander. Die spraak-taalterapeut gaan dus te doen kry met dialekte en taalvariasie in die verskillende gebiede waar dieselfde taal gepraat word. Die Sepedi-toets vir Spraakverstaanbaarheid verminder die probleem in 'n mate. Die kliënt moet die woorde lees soos wat dit geskryf is. Daar kan dus minder strukturele veranderings en variasies voorkom as wanneer die taal spontaan gepraat word.

Daar blyk nie werklik'n oplossing vir hierdie probleem te wees nie, omdat die taalverskeidenheid in die land so groot is. Meetinstrumente kan in elke amptelike taal ontwikkel word, maar die persone wat die intstrument moet gebruik, sal nie noodwendig moedertaalsprekers wees of oor enige kennis van die taal beskik nie. Die ideaal sou wees om meetinstrumente te ontwikkel wat universeel van aard is, en wat nie die terapeụt of kliënt benadeel nie. 'n Ander moontlikheid sou gewees het om die toets te kategoriseer om aan te pas by die persoon se dialek. Die uitvoerbaarheid van so 'n taak sal egter baie gekortwiek word deur die besondere hoë taalverskeidenheid in die land.

\section{GEWYSIGDE PROSEDURES VIR DIE EVALUERING DEUR DIE NIE-MOEDERTAALSPREKER.}

In die Afrikaanse Toets vir Spraakverstaanbaarheid van Disartriesprekers van Klopper (1983) asook in die bestaande Engels toets, nl. "Assessment of Intelligibility of Dysarthric Speech" van Yorkston en Beukelman (1981) word daar gebruik gemaak van die veelvuldige keuse metode asook die transkripsie-metode as beoordelingsmetodes. Tydens die uitvoering van die Sepedi-toets vir Spraakverstaanbaarheid het dit egter geblyk dat die evaluasiemetodes gewysig moet word om die probleme wat voorkom as gevolg van die meertaligheid, te verminder.

In die vorige gedeelte is reeds verwys na die feit dat daar van die klanke in die klankrepertoire van Sepedi voorkom, wat nie in Afrikaans of Engels gebruik word nie. Die gesproke taal klink dus baie vreemd vir die niemoedertaalspreker. Sepedi is ook'n toontaal (Kotze, 1990), 'n eienskap wat totaal onbekend is aan die nie-moedertaalspreker. Die eienskap is inherent aan die spraakproduksie van die moedertaalspreker. Baie min persone wat die taal wel as derde taal magtig is, kan hierdie verskille in toon uitken (Taljard, 1998). Dit is van die aspekte wat transkripsie van sinne deur die terapeut baie bemoeilik Die spraak klink vir die luisteraar na baie vinnige, onverstaanbare jargon wat nie gevolg kan word nie. Dit veroorsaak geweldige frustrasie aan die kant van die luisteraar, omdat dit nie net baie moeilik is om uit te voer nie, maar ook baie tydrowend is. Op hierdie wyse verlaag die betroubaarheid van die resultate wat verkry word. Die prosedure vir die evaluering van die sinne word dus gewysig vir die nie-moedertaalspreker. Die. wysiging vergemaklik die taak van die terapeut en verbeter die kliënt se kanse om beter te vaar op die toets.

In die genoemde toetse van Klopper (1983) en Yorkston en Beukelman (1981) word daar ook gebruik gemaak van 'n subjektiew.e evaluasie van spraakverstaanbaarheid. Uit hierdie studie het dit egter duidelik geblyk dat die gebruik van die subjektiewe evaluasie deur 'n nie-moedertaalspreker nie werkbaar is nie. Die onbekendheid van die taal aan die luisteraar bring mee dat die subjektiewe evaluering van 'n persoon se spraakverstaanbaarheid negatief beïnvloed word. Die subjektiewe evaluering van spraakverstaanbaarheid deur die nie-moedertaalspreker wat as luisteraar optree, word uitgelaat by die uitvoering van die Sepedi-toets vir Spraakverstaanbaarheid.

Daar word verder voorgestel dat groep 9 wat bestaan uit geaspireerde klusters, nie deur die nie-moedertaalspreker uitgevoer word nie. Die geaspireerde klanke is baie moeilik om te onderskei van ander klanke as die luisteraar nie bekend is daarmee nie.

Die toetsresultate wat verkry word deur die niemoedertaalspreker en moedertaalsprekers wat optree as luisteraars moenie met meer as $10 \%$ verskil nie. Indien die verskil groter is, kan die resultate nie as betroubaar geag word nie. Dit is belangrik dat die spraak-taalterapeut wat die toets gebruik, soms gebruik moet maak van 'n tweede luisteraar wat'n moedertaalspreker is.

\section{DIE AARD VAN SPRAAKVERSTAANBAARHEIDS- TOETSE}

Die grootste aantal spraakverstaanbaarheidstoetse wat beskikbaar is, vereis dat die toetsling moet kan lees. Wanneer die Spraakverstaanbaarheidstoetse, van Klopper (1983) en Yorkston en Beukelman (1981) uitgevoer word, word daar ook van die toetsling verwag om te kan lees. Die spraak-taalterapeut in Suid-Afrika word nie net gekonfronteer met meertaligheid nie, maar ook met kliënte wat nie altyd kan lees of skryf nie. Volgens statistiek, soos verkry van die Central Statistics (CSS), wat vrygestel is 1997 van die 1991 sensus (laaste beskikbare statistiek) was $82,16 \%$ van die totale bevolking op daardie stadium geletterd. Die CSS definieër geletterdheid as volg: die persoon kan sy moedertaal lees, skryf en praat. Die geletterdheid onder die Swart Suid-Afrikaners is $76 \%$ en in gebiede waar die grootste konsentrasie van Sepedi's is, is die totale geletterdheid van al die bevolkingsgroepe in die provinsies ongeveer $73 \%$. Daar is dus in Suid-Afrika 'n groot getal persone wat nog ongeletterd is. 'n Totaal van 
2864000 volwassenes in Suid-Afrika is ongeletterd en daarvan is 2640000 persone van die Swart bevolkingsgroepe. 'n Groot deel van hierdie persentasie persone bestaan uit persone van Swart bevolkingsgroepe van veral die plattelandse gebiede.

Die gebruik van die Sepedi-toets vir Spraakverstaanbaarheid word in 'n groot mate hierdeur geraak, omdat die kliënt die lyste moet kan lees. In die prosedure word daar wel aanbeveel dat die kliënt die woorde kan herhaal, maar dit verminder die waarde van die toets. 'n Luisteraar hoor dus beide produksies en die beoordeling van prestasie is dus onbetroubaar. Die navorser beveel nie hierdie prosedure aan, tensy dit onvermydelik is nie.

Verdere navorsing is nodig om te kyk of daar 'n addisionele afdeling by die toets gevoeg kan word wat die probleem van ongeletterdheid kan oorbrug. Daar kan gekyk word na die gebruik van prente met of sonder toepaslike vrae, om die verwagte respons te ontlok. Die vrae wat gebruik word om die respons te ontlok moet nie so wyd wees dat dit meer as die vereiste respons ontlok nie. Dit kan veroorsaak dat die persoon sinne, in plaas van woorde produseer. 'n Belangrike aspek wat te voorskyn kan kom by die gebruik van prente is 'die kwessie van die Koine-taal. Tydens die opstel van die Sepedi-toets vir Spraakverstaanbaarheid is daar gebruik gemaak van die standaardtaal, sodat die toets groter toepassingsmoontlikhede het. Prente kan egter woorde by die spreker ontlok wat gebiedsgebonde is. Dit is belangrik dat die aspek in ag geneem word wanneer die prente gebruik word. Die spraak-taalterapeut kan self prente versamel om te gebruik. Daar word egter aanbeveel dat die prente inpas by die milieu van die Sepedi-spreker, sodat die toetsling die prente herken. Prente vanuit die Westerse kultuur sal nie altyd toepaslik wees nie, omdat baie van die gebruike nie in die Afrika-kultutur voorkom nie. Die prente moet eenvoudig en duidelik wees, sodat 'n persoon wat swak sien, die prent duidelik kan sien. Te veel detail kan verwarrend wees en om slegs die vereiste woord te ontlok, moet daar so min moontlik items op die prent wees.

\section{SLOT}

Die Sepedi-toets vir Spraakverstaanbaarheid kan baie effektief in die Suid-Afrikaanse konteks gebruik word. Dit vergemaklik die taak van die spraak-taalterapeut wat in 'n meertalige situasie werk en nie altyd die kliënt se taal kan besig nie. Die probleem van meertaligheid sal nog vir baie lank in ons midde wees, maar die spraak-taalterapeut kan dit beskou as 'n uitdaging wat aan haar/hom gestel word om te kompenseer vir die gebrek aan taalvaardighede. Die uitdaging aan die spraak-taalterapeut wat in die opset werksaam is, is om steeds verantwoordbare dienste aan die kliënt te lewer en op so wyse by te dra tot die vooruitgang van die professie.

\section{VERWYSINGS}

Black, J.W. \& Haagen, C.H. (1963). Multiple choice intelligibility tests, forms

A \& B. Journal of Speech and Hearing Disorders, Vol. 28, pp. 77 $-86$.

Cannito, M.P. \& Marquardt, T.P. (1997). Ataxic Dysarthria. In McNeil M.R. (Ed) Clinical Management of Sensorimotor Speech Disorders. New York: Thieme Medical.

Central Statistics (CSS). (1997). Statistics in brief: RSA.

Darley, F.L., Aronson, A.E. \& Brown, J.R. (1975). Motor Speech Disorders. Philadelphia: Saunders.

Gillmer, E. (1982). 'n Ondersoek na die stemaanvangstyd van apraktiese en disartriesprekers. Ongepubliseerde B. Log Navorsingsverslag. Pretoria: Universiteit van Pretoria.

Joubert, A. M. (1996). Die opstel en uitvoering van SepediArtikulasietoets. Ongepubliseerde B. Kommunikasiepatologie Navorsingsverslag. Pretoria: Universiteit van Pretoria.

Klopper, K. (1983). Spraakverstaanbaarheid by Afrikaanse disartriesprehers: 'n Voorgestelde toets. Ongepubliseerde B.Log Navorsingsverslag. Pretoria: Universiteit van Pretoria.

Kock, J.H.M., \& Kock, S. D. (1991). Noord-Sotho vir die nuwe era 6. Kaapstad: Nasionale Opvoedkundige Uitgewery Beperk.

Kock, J.H.M., \& Kock, S. D. (1992). Noord-Sotho vir die nuwe era 7. Kaapstad: Nasionale Opvoedkundige Uitgewery Beperk.

Kotzé, A. E. (1990). An introduction to Northern Sotho Phonetics and Phonology. Houtbaai: Marius Lubbe Publishers.

Kriel, T.J. \& Van Wyk, E. B. (1989). Pukuntšu Woordeboek. Pretoria: J.L, van Schaik.

Pakendorf, C. (1996). The translation of the Peabody Picture Vocabulary Test: revised into Northern Sotho: a preliminary investigation. Ongepubliseerde M. Kommunikasiepatologie Verhandeling. Pretoria: Universiteit van Pretoria.

Schuring, G.K. (1984). Die Omgangs Sotho van die Swart woongebiede van Pretoria. Ongepubliseerde D. Litt. Verhandeling. Johannesburg: Randse Afrikaanse Universiteit.

Taljard, E. (1998). Persoonlike onderhoud: Beskrywing van die nie-moedertaalspreker en die gebruik van die toontaal. Universiteit van Pretoria, Pretoria, RSA.

Tikofsky, R.S. (1970). A revised list for the estimation of dysarthric speech. Journal of Speech and Hearing Research, Vol, 13, pp. 59-64.

Van Wyk, E.B., Groenewald, P.S., Prinsloo, D.J., Kock, J.H.M. \& Taljard, E. (1990). Noord Sotho vir Eerstejaars. Pretoria: J.L. van Schaik.

Yorkston, K.M. \& Beukelman, D.R. (1978). A comparison of techniques for measuring intelligibility of dysarthric speech. Journal of Speech and Hearing Research, Vol. 11, pp. 499512.

Yorkston, K.M. \& Beukelman, D.R. (1980). A clinician-judged technique for quantifying dysarthric speech based on single word intelligibility. Journal of Communication Disorders, Vol. 13 , pp. 15-31.

Yorkston, K.M. \& Beukelman, D.R. (1980). Influence of passage familiarity on intelligibility estimates of dysarthric speech. Journal of Communication Disorders, Vol. 13, pp. 33-41. |

Yorkston, K.M. \& Beukelman, D.R. (1981). Communication efficiency of dysarthric speakers as measured by sentence intelligibility and speaking rate. Journal of Speech and Hearing Disorders, Vol. 46, pp. 296 - 398.

Yorkston, K. M., Beukelman, D.R. \& Bell, K. R. (1988). Clinical Management of Disarthric Speakers. Texas: Pro-Ed. 
BYLAE A

VOORBEELD VAN TWEE WOORDELYSTE

Lenanêô 1 (Woordlys 1)

\begin{tabular}{|l|l|l|l|l|}
\hline 1. pêpa & 2. dila & 3. fapa & 4. gêsa & 5. kôpa \\
\hline 6. pula & 7. ripa & 8. mela & 9. poka & 10. pala \\
\hline 11. meta & 12. bôna & 13. tapa & 14. têma & 15. nôpa \\
\hline 16. lema & 17. tupa & 18. tima & 19. kwata & 20. tšêka \\
\hline 21. kgôpa & 22. kwara & 23. kwêna & 24. tšôla & 25. phaka \\
\hline 26. thata & 27. khuma & & \\
\hline
\end{tabular}

Lenanêô 2 (Woordlys 2)

\begin{tabular}{|c|c|c|c|c|}
\hline 1. pešo & 2. bêka & 3. gaša & 4. pêta & 5. pôna \\
\hline 6. ruta & 7. fira & 8. peka & 9. kona & 10. bata \\
\hline 11. bela & 12. pôta & 13. taba & 14. nêpa & 15. lôba \\
\hline 16. tepa & 17. tuba & 18. ripa & 19. tsaka & 20. kgêka \\
\hline 21. tšôka & 22. tsama & 23. tsêna & 24. kgôga & 25. phapa \\
\hline 26. thaba & 27. khuna & & & \\
\hline
\end{tabular}

\section{BYLAE B}

\section{VOORBEELD VAN LUISTERAARSANTWOORDBLAD}

\begin{tabular}{|c|c|c|c|c|c|c|c|c|}
\hline $\begin{array}{l}\text { 1. pêpa } \\
\text { [pєpa] }\end{array}$ & $\begin{array}{l}\text { fêpa } \\
\text { ffepa] }\end{array}$ & $\begin{array}{l}\text { lêpa } \\
\text { [lepa] }\end{array}$ & $\begin{array}{ll}5 . & \text { kêpa } \\
& {[\mathrm{k \varepsilon pa}]}\end{array}$ & $\begin{array}{l}\text { kapa } \\
\text { [ka:pa] }\end{array}$ & $\begin{array}{l}\text { kôpa } \\
{\left[\begin{array}{ll}\mathrm{k} & \mathrm{pa}\end{array}\right]}\end{array}$ & $\begin{array}{cc}\text { 9. } & \text { poka } \\
& \text { [poka] }\end{array}$ & $\begin{array}{l}\text { peka } \\
\text { [peka] }\end{array}$ & $\begin{array}{l}\text { paka } \\
\text { [pa:ka] }\end{array}$ \\
\hline $\begin{array}{l}\text { pešo } \\
{\left[\text { pe } \int_{0}\right]}\end{array}$ & $\begin{array}{l}\text { bešo } \\
{\left[\text { be } \int_{0}\right]}\end{array}$ & $\begin{array}{l}\text { mešo } \\
{[\text { mefo] }}\end{array}$ & $\begin{array}{l}\text { pina } \\
\text { [pina] }\end{array}$ & $\begin{array}{l}\text { pêna } \\
\text { [pena] }\end{array}$ & $\begin{array}{l}\text { pôna } \\
\text { [pona] }\end{array}$ & $\begin{array}{l}\text { kona } \\
\text { [kona] }\end{array}$ & $\begin{array}{l}\text { kina } \\
\text { [kina] }\end{array}$ & $\begin{array}{l}\text { kana } \\
\text { [ka:na] }\end{array}$ \\
\hline $\begin{array}{l}\text { sêka } \\
\text { [seka] }\end{array}$ & $\begin{array}{l}\text { têka } \\
\text { [teka] }\end{array}$ & $\begin{array}{l}\text { nêka . } \\
\text { [neka] }\end{array}$ & $\begin{array}{l}\text { sêka } \\
\text { [sckka] }\end{array}$ & $\begin{array}{l}\text { saka } \\
\text { [sa:ka] }\end{array}$ & $\begin{array}{l}\text { sôka } \\
\text { [spt ka] }\end{array}$ & $\begin{array}{l}\text { lota } \\
\text { [lota] }\end{array}$ & $\begin{array}{l}\text { leta } \\
\text { \leta }\rceil\end{array}$ & $\begin{array}{l}\text { lata } \\
\text { [la:ta] }\end{array}$ \\
\hline $\begin{array}{l}\text { fêfa } \\
\text { [fعfa] }\end{array}$ & $\begin{array}{l}\text { bêfa } \\
{[\beta \varepsilon f a]}\end{array}$ & $\begin{array}{l}\text { lêfa } \\
{[l \varepsilon f a]}\end{array}$ & $\begin{array}{l}\text { sêla } \\
\text { [scla] }\end{array}$ & $\begin{array}{l}\text { sala } \\
\text { [sa:la] }\end{array}$ & $\begin{array}{l}\text { sôla } \\
\text { [so la] }\end{array}$ & $\begin{array}{l}\text { goša } \\
\text { [xola] }\end{array}$ & $\begin{array}{l}\text { gaša } \\
\text { [xa:la] }\end{array}$ & $\begin{array}{l}\text { gêša } \\
[x \varepsilon] \mathrm{a}]\end{array}$ \\
\hline $\begin{array}{l}\text { 2. kita } \\
\text { [kita] }\end{array}$ & $\begin{array}{l}\text { dita } \\
\text { [dita] }\end{array}$ & $\begin{array}{l}\text { tita } \\
\text { [tita] }\end{array}$ & $\begin{array}{l}\text { 6. } \\
\text { kupa } \\
\text { [kupa] }\end{array}$ & $\begin{array}{l}\text { kôpa } \\
{[\mathrm{k}(\mathrm{pa}]}\end{array}$ & $\begin{array}{l}\text { kapa } \\
\text { [ka:pa] }\end{array}$ & $\begin{array}{l}\text { 10. } \text { pôta } \\
{[\mathrm{p}(\mathrm{ta}]}\end{array}$ & $\begin{array}{l}\text { pata } \\
\text { [pa:ta] }\end{array}$ & $\begin{array}{l}\text { puta } \\
\text { [puta] }\end{array}$ \\
\hline $\begin{array}{l}\text { tila } \\
\text { [tila] }\end{array}$ & $\begin{array}{l}\text { dila } \\
\text { [dila] }\end{array}$ & $\begin{array}{l}\text { kila } \\
\text { [kila] }\end{array}$ & $\begin{array}{l}\text { pula } \\
\text { [pula] }\end{array}$ & $\begin{array}{l}\text { pola } \\
\text { [pola] }\end{array}$ & $\begin{array}{l}\text { pala } \\
\text { [pa:la] }\end{array}$ & $\begin{array}{l}\text { pola } \\
\text { [pola }]\end{array}$ & $\begin{array}{l}\text { pala } \\
\text { [pa:la] }\end{array}$ & $\begin{array}{l}\text { pula } \\
\text { [pula] }\end{array}$ \\
\hline $\begin{array}{l}\text { sêka } \\
\text { [scka] }\end{array}$ & $\begin{array}{l}\text { bêka } \\
\text { [ßઘka] }\end{array}$ & $\begin{array}{l}\text { fêka } \\
\text { [fєka] }\end{array}$ & $\begin{array}{l}\text { ruta } \\
\text { [ruta] }\end{array}$ & $\begin{array}{l}\text { rota } \\
{[\text { rota] }}\end{array}$ & $\begin{array}{l}\text { rata } \\
\text { [ra:ta] }\end{array}$ & $\begin{array}{l}\text { beta } \\
{[\beta \text { Beta }]}\end{array}$ & $\begin{array}{l}\text { bata } \\
{[\beta \mathrm{a}: \mathrm{ta}]}\end{array}$ & $\begin{array}{l}\text { bita } \\
{[\beta i t a]}\end{array}$ \\
\hline $\begin{array}{l}\text { fase } \\
\text { [fa:se] }\end{array}$ & $\begin{array}{l}\text { lase } \\
\text { [la:se] }\end{array}$ & $\begin{array}{l}\text { gase } \\
\text { [xa:se] }\end{array}$ & $\begin{array}{l}\text { rufa } \\
\text { [rufa] }\end{array}$ & $\begin{array}{l}\text { rafa } \\
\text { [ra:fa] }\end{array}$ & $\begin{array}{l}\text { rifa } \\
\text { [rifa] }\end{array}$ & $\begin{array}{l}\text { mena } \\
=[\text { mena }]\end{array}$ & $\begin{array}{l}\text { mana } \\
\text { [ma:na] }\end{array}$ & $\begin{array}{l}\operatorname{mina} \\
\text { [mina] }\end{array}$ \\
\hline $\begin{array}{l}\text { 3. padi } \\
\text { [pa:di] }\end{array}$ & $\begin{array}{l}\text { pêdi } \\
\text { [pedi] }\end{array}$ & $\begin{array}{l}\text { podi } \\
\text { [podi] }\end{array}$ & $\begin{array}{ll}\text { 7. } & \text { kôta } \\
& {[\mathrm{ko} \text { ta] }}\end{array}$ & $\begin{array}{l}\text { kita } \\
\text { [kita] }\end{array}$ & $\begin{array}{l}\text { kuta } \\
\text { [kuta] }\end{array}$ & $\begin{array}{ll}\text { 11. } & \text { pôta } \\
& {[\mathrm{pota} \text { ta] }}\end{array}$ & $\begin{array}{l}\text { puta } \\
\text { [puta] }\end{array}$ & $\begin{array}{l}\text { peta } \\
\text { [peta] }\end{array}$ \\
\hline $\begin{array}{l}\text { pala } \\
\text { [pa:la] }\end{array}$ & $\begin{array}{l}\text { pela } \\
\text { [pela] }\end{array}$ & $\begin{array}{l}\text { pola } \\
\text { [pola] }\end{array}$ & $\begin{array}{l}\text { pôna } \\
\text { [po na] }\end{array}$ & $\begin{array}{l}\text { pina } \\
\text { [pina] }\end{array}$ & $\begin{array}{l}\text { pêna } \\
\text { [pena] }\end{array}$ & $\begin{array}{l}\text { pola } \\
\text { [pola] }\end{array}$ & $\begin{array}{l}\text { pala } \\
\text { [pa:la] }\end{array}$ & $\begin{array}{l}\text { pela } \\
\text { [pela] }\end{array}$ \\
\hline $\begin{array}{l}\text { fapa } \\
\text { fa:pa] }\end{array}$ & $\begin{array}{l}\text { fêpa } \\
\text { [fєpa] }\end{array}$ & $\begin{array}{l}\text { fopa } \\
\text { fopa] }\end{array}$ & $\begin{array}{l}\text { rapa } \\
{[\mathrm{ra}: \mathrm{pa}]}\end{array}$ & $\begin{array}{l}\text { ripa } \\
\text { [ripa] }\end{array}$ & $\begin{array}{l}\text { rupa } \\
\text { [rupa] }\end{array}$ & $\begin{array}{l}\text { mota } \\
{[\text { mota }]}\end{array}$ & $\begin{array}{l}\text { mata } \\
{[\mathrm{ma}: \mathrm{ta}]}\end{array}$ & $\begin{array}{l}\text { meta } \\
{[\text { meta] }}\end{array}$ \\
\hline $\begin{array}{l}\text { gaša } \\
\text { [xa: a] }\end{array}$ & $\begin{array}{l}\text { gêša } \\
{\left[x \varepsilon \int a\right]}\end{array}$ & $\begin{array}{l}\text { goša } \\
{\left[\mathrm{xo} \int \mathrm{a}\right]}\end{array}$ & $\begin{array}{l}\text { fura } \\
\text { [fura] }\end{array}$ & $\begin{array}{l}\text { fira } \\
\text { [fira] }\end{array}$ & $\begin{array}{l}\text { fora } \\
\text { [fora }]\end{array}$ & $\begin{array}{l}\text { bula } \\
{[\beta \text { ula }]}\end{array}$ & $\begin{array}{l}\text { bala } \\
{[\beta a: l a]}\end{array}$ & $\begin{array}{l}\text { bela } \\
{[\text { Bela }]}\end{array}$ \\
\hline $\begin{array}{l}\text { 4. pata } \\
\text { [pa:ta] }\end{array}$ & $\begin{array}{l}\text { pêta } \\
\text { [peta] }\end{array}$ & $\begin{array}{l}\text { puta } \\
\text { [puta] }\end{array}$ & $\begin{array}{ll}\text { 8. } & \text { puka } \\
1 & \text { [puka] }\end{array}$ & $\begin{array}{l}\text { poka } \\
\text { [poka] }\end{array}$ & $\begin{array}{l}\text { peka } \\
\text { [peka] }\end{array}$ & $\begin{array}{l}\text { 12. pôta } \\
\text { [po ta] }\end{array}$ & $\begin{array}{l}\text { pata } \\
\text { [pa:ta] }\end{array}$ & $\begin{array}{l}\text { puta } \\
\text { [puta] }\end{array}$ \\
\hline $\begin{array}{l}\text { pošo } \\
{\left[p o \int_{0}\right]}\end{array}$ & $\begin{array}{l}\text { pêšo } \\
{\left[p \varepsilon \int 0\right]}\end{array}$ & $\begin{array}{l}\text { pušo } \\
{\left[p u \int_{0}\right]}\end{array}$ & $\begin{array}{l}\text { pola } \\
\text { [pola] }\end{array}$ & $\begin{array}{l}\text { pula } \\
\text { [pula] }\end{array}$ & $\begin{array}{l}\text { pela } \\
\text { [pela] }\end{array}$ & $\begin{array}{l}\text { pôna } \\
\text { [pona] }\end{array}$ & $\begin{array}{l}\text { pina } \\
\text { [pina] }\end{array}$ & $\begin{array}{l}\text { pana } \\
\text { [pa:na] }\end{array}$ \\
\hline $\begin{array}{l}\text { fapa } \\
\text { [fa:pa] }\end{array}$ & $\begin{array}{l}\text { fêpa } \\
\text { [fєpa] }\end{array}$ & $\begin{array}{l}\text { fopa } \\
\text { [fopa] }\end{array}$ & $\begin{array}{l}\text { saka } \\
\text { [sa:ka] }\end{array}$ & $\begin{array}{l}\text { soka } \\
\text { [soka] }\end{array}$ & $\begin{array}{l}\text { seka } \\
\text { [seka] }\end{array}$ & $\begin{array}{l}\text { bôta } \\
{[\beta o \mathrm{ta}]}\end{array}$ & $\begin{array}{l}\text { beta } \\
{[\text { ßeta] }}\end{array}$ & $\begin{array}{l}\text { bita } \\
{[\beta \text { ita }]}\end{array}$ \\
\hline $\begin{array}{l}\text { goša } \\
\text { [xofa] }\end{array}$ & $\begin{array}{l}\text { gêša } \\
{\left[x \varepsilon \int a\right]}\end{array}$ & $\begin{array}{l}\text { gaša } \\
\text { [xa:Ja] }\end{array}$ & $\begin{array}{l}\text { mola } \\
{[\text { mola }]}\end{array}$ & $\begin{array}{l}\text { mala } \\
\text { [ma:la] }\end{array}$ & $\begin{array}{l}\text { mela } \\
\text { [mela] }\end{array}$ & $\begin{array}{l}\text { bôna } \\
\text { [ßßo na] }\end{array}$ & $\begin{array}{l}\text { bina } \\
\text { [Eßina] }\end{array}$ & $\begin{array}{l}\text { buna } \\
\text { [ßuna] }\end{array}$ \\
\hline
\end{tabular}

